\title{
Erotylidae (Insecta, Coleoptera) of Poland - problematic taxa, updated keys and new records
}

\author{
Rafał Ruta', Paweł Jałoszyński ${ }^{2}$ Paweł Sienkiewicz ${ }^{3}$, Szymon Konwerski ${ }^{4}$ \\ I Department of Biodiversity and Evolutionary Taxonomy, Zoological Institute, Wroctaw University, \\ Przybyszewskiego 63/77, 51-148 Wroctaw, Poland 2 Museum of Natural History, Wroctaw University, \\ Sienkiewicza 21, 50-335 Wroctaw, Poland 3 Department of Entomology and Landscape Protection, Poznan \\ University of Life Sciences, Dąbrowskiego 159, 60-594 Poznań, Poland 4 Natural History Collections, Adam \\ Mickiewicz University, Umultowska 89, 61-614 Poznań, Poland \\ Corresponding author: Rafat Ruta (scirtes@biol.uni.wroc.pl)
}

Academic editor: Michael Thomas | Received 7 June 2011 | Accepted 30 August 2011 | Published 6 October 2011

Citation: Ruta R, Jałoszyński P, Sienkiewicz P, Konwerski S (2011) Erotylidae (Insecta, Coleoptera) of Poland problematic taxa, updated keys and new records. ZooKeys 134: 1-13. doi: 10.3897/zookeys.134.1673

\begin{abstract}
New data concerning the occurrence of pleasing fungus beetles (Coleoptera: Erotylidae) in Poland are given, with a focus on rare and difficult to identify Central European taxa. Cryptophilus cf. integer (Heer) (Cryptophilinae) is reported from the Polish territory for the first time based on adult and larval specimens collected in the Wielkopolska-Kujawy Lowland. Identification problems concerning species of Cryptophilus introduced to Europe are discussed. Triplax carpathica Reitter (Erotylinae) is recorded from the Białowieża Primeval Forest, which is the first known non-Carpathian finding of this species, located in the close proximity of the Polish-Belarussian UNESCO World Heritage Site "Białowieża Forest". Discussion of T. carpathica being conspecific with Siberian T. rufiventris Gebler is provided. New Polish localities of several other Erotylidae are reported, and an updated key to Central European species of Triplax is given. The Triplax key is supplemented with dorsal and ventral habitus images of all treated Triplax species. One of the rarest Central European erotyline species Combocerus glaber (Schaller) is recorded from xerothermic grasslands in North-West Poland.
\end{abstract}

\section{Keywords}

Coleoptera, Erotylidae, Cryptophilinae, Erotylinae, Cryptophilus, Triplax carpathica, new records, Central Europe, Poland, Białowieża Primeval Forest

Copyright R. Ruta et al. This is an open access article distributed under the terms of the Creative Commons Attribution License, which permits unrestricted use, distribution, and reproduction in any medium, provided the original author and source are credited. 


\section{Introduction}

The systematics of pleasing fungus beetles (Erotylidae) has undergone significant changes within the past decade, and according to the currently accepted classification (Wegrzynowicz 2007) all species hitherto known to occur in Poland belong to the subfamily Erotylinae. Four genera have been recorded from Poland: Combocerus Bedel, Dacne Latreille (both in the tribe Dacnini), Triplax Herbst and Tritoma Fabricius (tribe Tritomini) (Mazur 1983; Burakowski et al. 1986; Węgrzynowicz 2007). The larvae of Combocerus remain unknown, but adults occur in plant debris (Franc 2001); whereas the remaining genera develop in saproxylous fungi (Burakowski et al. 1986). Most European Erotylidae are included in the European red list of saproxylic beetles (Nieto and Alexander 2010).

Distributions of most Erotylidae in Poland are inadequately known and published faunistic data are relatively scarce. Some species have only been recorded from the southern arch of mountains or from few localities within the most species-rich (and intensively surveyed) national parks, but their true ranges may be broader. For example, Triplax collaris (Schaller) was previously known in Poland only in the Białowieża Primeval Forest (Burakowski et al. 1986), but it was recently found in a distant and distinctly different forest near Poznań (Jałoszyński and Węgrzynowicz 2007).

Herein, we extend the Polish checklist of pleasing fungus beetles by reporting new findings; we also give new district records of several rare Erotylidae, and discuss taxonomic problems concerning two species.

\section{Methods and conventions}

Depositories: $[\mathrm{HNHM}]$ - Hungarian Museum of Natural History (Budapest, Hungary); [LBJK] - coll. L. Borowiec et J. Kania (Wrocław, Poland); [MIZ] - Museum and Institute of Zoology of Polish Academy of Sciences (Warsaw, Poland); [MNHW] - Museum of Natural History, Wrocław University (Wrocław, Poland); [SMNS] Staatliches Museum für Naturkunde (Stuttgart, Germany); [PJ] - coll. P. Jałoszyński (Wrocław, Poland); [RR] - coll. R. Ruta (Wrocław Poland); [SK] - coll. S. Konwerski (Poznań, Poland).

Specimen handling and imaging. Dry-mounted adult specimens and an ethanol-preserved larva were used for the study; when necessary beetles were detached in warm water from mounting cards to examine ventrites. The body length was measured from the anterior margin of pronotum to the apex of elytra. Specimens showed on color plates are from MIZ, SMNS, PJ and RR. Habitus images were taken by a Nikon Coolpix 4500 camera mounted to a Nikon SMZ 1500 dissecting microscope (all species of Triplax) or by an Olympus C-750UZ camera equipped with a Raynox MSN-505 close-up lens (larva and adult of Cryptophilus). Image stacks were processed using Helicon Focus 4.62 and Photoshop 7.0 CE (Triplax) or Combine ZP and Corel Photo-Paint 8 (Cryptophilus). Scanning electron micrographs of uncoated specimens were taken by a HITACHI S-3400N scanning electron microscope at MIZ. 
Collectors: JK - J. Kania; JMG - J. M. Gutowski; JS - J. Szypuła; JSA - J. Sawoniewicz; KK - K. Kowalczyk; LB - L. Borowiec; LBU - L. Buchholz; MW - M. Wanat; PJ - P. Jałoszyński; PS - P. Sienkiewicz; RR - R. Ruta; SK - S. Konwerski.

Other abbreviations: f. sec. - forest section; nat. res. - nature reserve; N.P. - national park; BL - body length; BW - maximum body width. An asterisk is used to mark first species records for particular districts of Poland (according to the division of Burakowski et al. 1973).

\section{Taxonomy}

\section{Cryptophilus cf. integer (Heer, 1841)}

http://species-id.net/wiki/Cryptophilus_integer

Figs 1, 2

Material examined. Poland*, Wielkopolska-Kujawy Lowland: Włocławek (UTM: CD63), compost heap, 1 adult and 1 larva, 26 VIII 2010, leg. PJ [PJ].

In the Palearctic Region, Cryptophilinae are represented by a single species of the East Chinese genus Chinophagus Lyubarsky, and the broadly distributed Cryptophilus Reitter with nine species (Wegrzynowicz 2007). External morphology of Cryptophilus superficially resembles that of many Cryptophagidae and for a long time members were placed in that family, despite historical work by Ganglbauer who reclassified Erotylidae and included Cryptophilus in Diphyllini, Erotylinae (Ganglbauer 1899). However, Ganglbauer's broad concept of Erotylidae (including Cryptophagidae and Biphyllidae) was disputable and not followed by subsequent authors. Cryptophilus was included in Languriidae (currently Languriinae within Erotylidae) by Sen Gupta and Crowson (1971) and Lawrence (1991); in Erotylidae, Cryptophilinae by Chûjô (1969); in Erotylidae, Xenoscelinae by Węgrzynowicz (2002); and in Erotylidae, Cryptophilinae in major modern catalogues and revisions (e.g. Leschen and Buckley 2007; Węgrzynowicz 2007).

The only Cryptophilus species reported from many European countries, including western and southern neighbours of Poland, is $C$. integer (Heer, 1841). The species was originally described in Cryptophagus Herbst, and indeed can be easily misidentified by an inexperienced coleopterist as a member of the Cryptophagidae. The latter family has never been popular among Polish entomologists and species in some genera (e.g. Cryptophagus) are difficult to identify. Therefore, the fact that Cryptophilus has been found only recently in Poland can be explained either by a possible misidentification as Cryptophagidae in institutional and private collections, or by current expansion or introduction. The major difference between cryptophagids and cryptophilines is the developement of the procoxal sockets, which are open or nearly open in Cryptophagidae and closed in Erotylidae. The larvae of Cryptophilus (Fig. 2) can be possibly misidentified as Monotoma Herbst (Monotomidae) or Epuraea Erichson (Nitidulidae); they all share a similar body shape and granulate or tuberculate dorsum, and occur in 


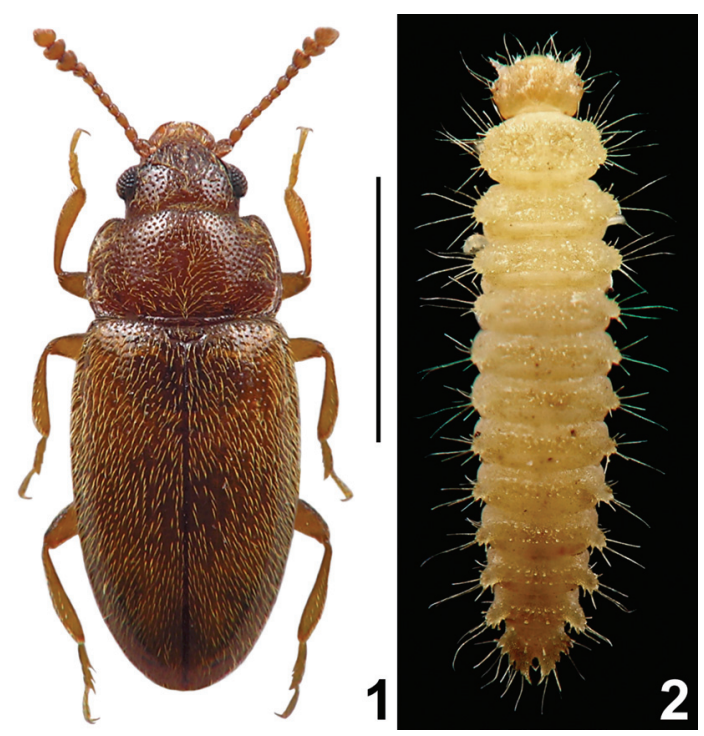

Figures I-2. Cryptophilus cf. integer (HeER); habitus of adult $\mathbf{I}$ and larva $\mathbf{2}$ Scale bar $=1 \mathrm{~mm}$.

similar habitats (often together). Unambiguous determination of Central European specimens can be made based on structures of the head capsule, mouthparts and terminal abdominal segments. Among others, the shape of the mandibles is clearly different: in Cryptophilus the prostheca is very large, subtriangular, and the mandible lacks a subapical accessory tooth; in Monotoma the prostheca is inconspicuous and the subapical accessory tooth present, very long and slender; in Epuraea the prostheca is developed as an elongate brush of hairs and the accessory tooth is absent.

Cryptophilus integer is associated with decaying plant matter (e.g. compost heaps). The genus needs a comprehensive revision before world species can be confidently identified. Due to this taxonomic problem the true identity of species recorded from Europe requires verification by specialists (Węgrzynowicz, pers. comm.). Therefore, although presenting the first Polish finding of Cryptophilus is justified, the identification of specimens must be treated as uncertain. Therefore we treat all previously published European records of Cryptophilus as tentatively identified pending verification by comparison of type specimens.

Triplax carpathica Reitter, 1890

http://species-id.net/wiki/Triplax_carpathica

Figs 4, 15

Type material examined. Holotype, Romania (originally "Hungaria bor."), Marmaros, Coll. Reitter [HNHM].

New material: Poland, Białowieża Primeval Forest*: Czerlonka vic., f. sec. 494 (FD84), 1 X 2000, 1 ex., leg. JMG [RR]; Olszanka-Myśliszcze nat. res. (FD83), 17 
VIII 2000, 1 ex., leg. MW [MNHW]. Bieszczady Mts.: Wetlina, Muchanin Wierch (FV04), 20 VIII 1970, 6 exx. [MIZ].

Among the beetles recently collected in the Białowieża Primeval Forest, two specimens possibly belonging to T. carpathica were found. This species was described from Romanian Carpathians (Reitter 1890), and recorded in Poland only from Bieszczady Mts. (Borowiec 1984). Its occurrence outside the Carpathian Range in northeastern Poland seemed highly unlikely. To unambiguosly confirm the species identity, the holotype of T. carpathica was examined, and the Polish specimens were found to be conspecific with the type. It is plausible that Triplax carpathica is another species with primarily Eastern Palearctic distribution that extends westwards to the Białowieża Primeval Forest in Central Europe (see the discussion of taxonomic problems below). The rare beetles Pytho kolwensis Sahlberg (Pythidae) and Xylobanellus erythropterus (Baudi) (Lycidae) are other examples of a similar distribution. The new findings of T. carpathica confirm the important value of woodlands surrounding the protected part of the Białowieża Forest, which is one of the last and largest primeval forests in Europe. Only a part of the forest is currently included in the Białowieża National Park and a UNESCO World Heritage Site. However, adjacent unprotected areas also show a remarkable biodiversity and may be important for survival of disjunct populations of $T$. carpathica and other rare insects.

A taxonomic problem was encountered when characters of the holotype of T. carpathica were compared with existing descriptions and keys. Previously, the only feature reported to differentiate T. carpathica from the East Palearctic T. rufiventris Gebler, 1823 ( $=$ T. amurensis Reitter, 1879), i.e. presence/absence of femoral lines, seemed dubious at best. Iablokoff-Khnzorian (1975) in his identification key stated that T. carpathica, but not T. rufiventris, has all femoral lines present ("toutes les lignes fémorales présentes"). However, the holotype of T. carpathica exhibits no traces of femoral lines on the metaventrite. Unfortunately, we were not able to study the type specimens of T. rufiventris and T. amurensis (both presumably in the Muséum National d'Histoire Naturelle, Paris) to clarify the true status of these taxa. A comprehensive revision of Palearctic Triplax remains beyond the scope of the present paper. However, we note that the identity of some species and their geographic distributions remain unclear and require further study.

\section{Triplax aenea (Schaller, 1783)}

http://species-id.net/wiki/Triplax_aenea

Figs 3,14

Material examined. Baltic Coast: Lubin (VV66), Wolin Is., 3 V 1991, 5 exx., leg. MW [MNHW]. Pomeranian Lake District*: Szczecin (VV71), 2 VI 2004, 2 exx. caught in sticky trap on Aesculus hippocastanum in city park "Ogród Dendrologiczny im. Stefana Kownasa”, leg. SK [SK], 3 VI 2004, 3 exx. under bark of a rotten trunk in city park "Park im. Fryderyka Chopina", leg. SK [SK]; Stara Rudnica (VU45) ad 

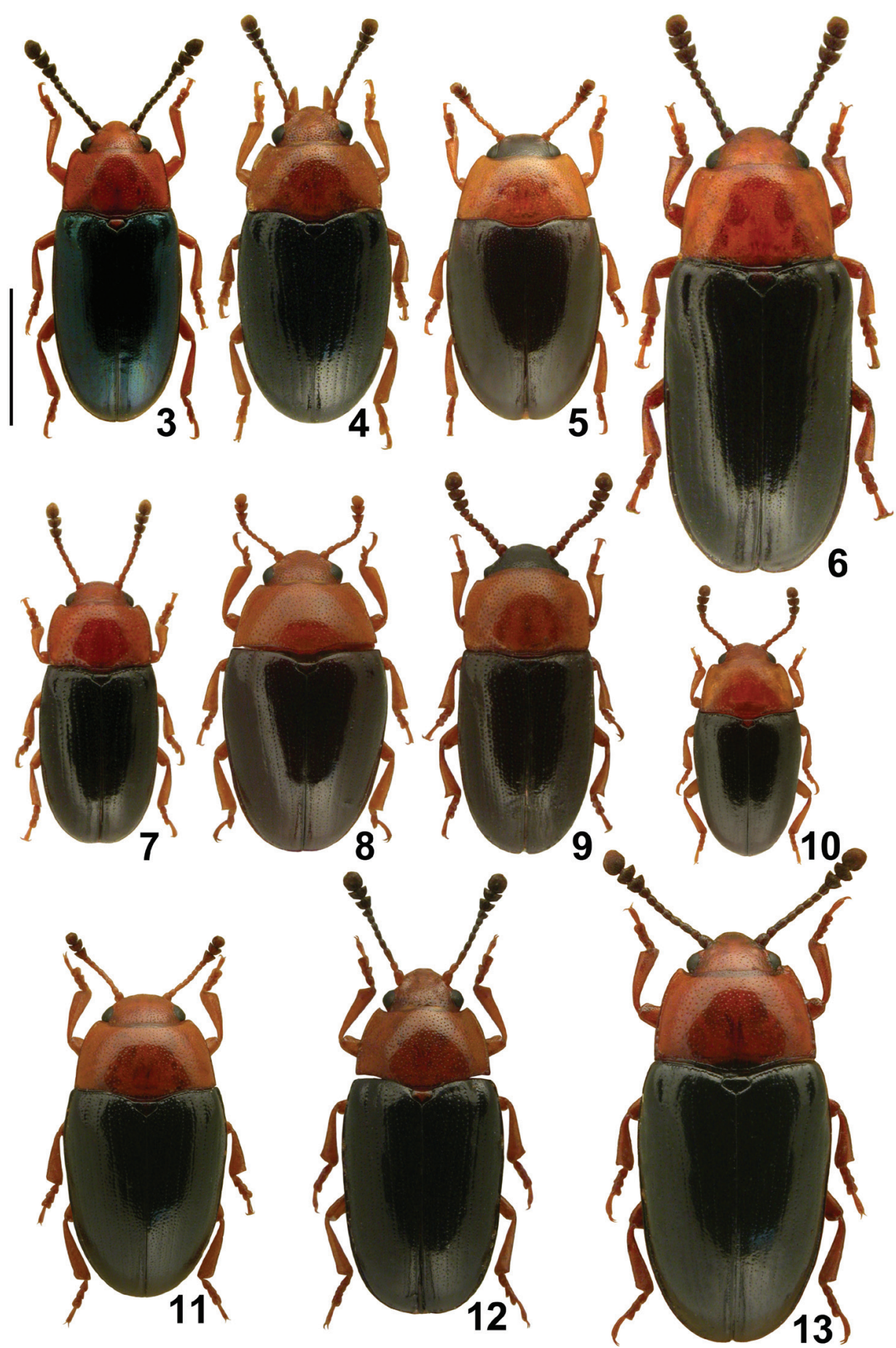

Figures 3-13. Central European species of Triplax, dorsal habitus: T. aenea $\mathbf{3}$ T. carpathica 4 T. collaris $\mathbf{5}$ T. elongata $\mathbf{6}$ T. Lacordairei $\mathbf{7}$ T. lepida $\mathbf{8}$ T. melanocephala $\mathbf{9}$ T. pygmaea $\mathbf{1 0}$ T. rufipes II T. russica $\mathbf{I} \mathbf{2}$ and T. scutellaris $\mathbf{3}$ Scale bar $=1.0 \mathrm{~mm}$. 
Cedynia, 29 IV 2010, 1 ex. on freshly cut poplar, moist meadow, leg. PJ [PJ]. Podlasie*: Sobibór (FC80) ad Włodawa, ad Bug river (sifted), 28 VII 2001, 1 ex., leg. MW [MNHW]. Białowieża Primeval Forest: Białowieża (FD94), meadows near N.P. 13 VI 1983, 3 exx., leg. MW [MNHW]; Białowieża N.P. (FD94), 15-27 VI 1991, 1 ex., leg. LB [LBJK], f. sec. 398, 27 VI 1991, 1 ex., leg. MW [MNHW]. Lower Silesia: Wrocław-Świniary (XS37), 27 IV 1991, 4 exx., leg. LB [LBJK]. Kraków-Wieluń Upland: Ojcowski N.P., Chełmowa Góra (DA16), 13 VI -1 VII 2004, 1 ex., leg. LBU [RR]. Roztocze*: Bukowa Góra nat. res. (FB30), 21 IX 1987, 3 exx., 9 VI 1988, 2 exx., 12 VI 1989, 3 exx., 17 VI 1989, 1 ex., leg. LB [LBJK], 22-23 VI 1990, 2 exx., leg. JK [LBJK]. Bieszczady Mts.: Wetlina PGR (FV04), 20 VII 1994, 4 exx., 22 VII 1994, 2 exx., leg. LB [LBJK]; Wetlina-Jawornik (FV04), 22 VII 1968, 1 ex., leg. K. Smulikowski [MIZ].

One of the most common Triplax species in Poland, but previously not recorded from several districts.

Triplax collaris (Schaller, 1783)

http://species-id.net/wiki/Triplax_collaris

Figs 5, 16

Material examined. Białowieża Primeval Forest: Białowieża vic. (FD84), f. sec. 425, oak-hornbeam forest, 12 VI 1983, 1 ex., leg. MW [MNHW]; Białowieża N.P. (FD94), 15-27 VI 1991, 10 exx., leg. LB, f. sec. 399, 18 VI 1991, 1 ex., leg. JK [LBJK].

The only well documented localities of this rare species are in the Białowieża Primeval Forest and Wielkopolska-Kujawy Lowland (Jałoszyński and Węgrzynowicz, 2007).

Triplax rufipes (Fabricius, 1787)

http://species-id.net/wiki/Triplax_rufipes

Figs 11, 22

Material examined. Podlasie*: Białystok (FD49), Antoniuk nat. res., 11 VII 2001, 1 ex., leg. JSA [MNHW]; Białowieża (FD94), meadows near N.P. 13 VI 1983, 3 exx., leg. MW [MNHW]; Białowieża N.P. (FD94), f. sec. 368/398/399, 2 exx., leg. MW [MHNW]. Roztocze*: Bukowa Góra nat. res. (FB30), 9 VI 1988, 2 exx., 8 VI 1989, 2 exx., leg. LB [LBJK], 22-23 VI 1990, 4 exx., leg. JK et LB [LBJK]. Świętokrzyskie Mts.: Białe Ługi nat. res. (DB82), 8 VII 2007, 1 ex., leg. RR [RR]; Świętokrzyski N.P., Święta Katarzyna (DB93), f. sec. 147g, 12-25 VIII 2009, 1 ex., leg. LBU [RR]. Sudety Zachodnie Mts.*: Szklarska Poręba Średnia (WS33), 16-24 VII 1995, 1 ex., leg. LB $[\mathrm{LBJK}]$.

A rare species, recently recorded from the southern part of Poland. 
Triplax russica (Linnaeus, 1758)

http://species-id.net/wiki/Triplax_russica

Figs 12, 23

Material examined. Pomeranian Lakeland: Bielinek nad Odrą (VU46), 29 IV 2010, 2 exx. on Polyporaceae fungi growing on a beach tree, leg. PJ \& PS [PJ]; Bukowskie Bagno nat. res. (WU98) ad Niekursko, 30 V 2006, 1 ex., leg. RR [RR]. WielkopolskaKujawy Lowland: Biedrusko vic. (XU22), military range, 24 VI 2006, 1 ex., 20 VIII 2007, 1 ex., both in hornbeam-oak forest, leg. SK [SK]; Rogalin (XT38) ad Poznan, 17 V 2011, leg. PS [PJ]; Piła-Kalina (XU28), 9 V 1998, 1 ex., leg. RR [RR]; Skoroszów (XT50), 6 VIII 1991, 1 ex., leg. LB [LBJK]; Stawy Przemkowskie nat. res. (WT51), 20 V 2007, 1 ex., leg. LB [LBJK]; Poznań, Maltańskie lake (XU30), 14 VI 2004, 1 ex. on a sticky trap on a pine tree, leg. SK [PJ]; Puszczykowo vic. ad Poznań (XT29), $21 \mathrm{~V} 2010,1$ ex. on a fungus growing on a beech tree; 8 VI 2010, 2 exx. on a fungus growing on a beech tree, leg. PJ [PJ]; Buczyna Szprotawska (WT40), 19 V 2007, 2 exx., leg. RR [RR]. Podlasie*: Sobibór (FC80) ad Włodawa, ex Leccinum scabrum, 4-6 VIII 2000, 1 ex., leg. MW [MNHW]. Lower Silesia: Lwówek Śląski (WS46), in an oak alley, VII 2007, 1 ex., leg. RR [RR]. Świętokrzyskie Mts.: Św. Krzyż (EB03), 6 VII 1978, 6 exx., leg. KK [MNHW], 21 V 1992, 3 exx., leg. LB [LBJK]. Roztocze: Bukowa Góra nat. res. (FB30), 9 VI 1988, 2 exx., 17 VI 1989, 1 ex., leg. LB [LBJK], 22-23 VI 1990, 2 exx., leg. JK [LBJK]. Bieszczady Mts.: Wetlina PGR (FV04), 22 VII 1994,2 exx., leg. LB [LBJK]; Wetlina-Jawornik (FV04), 22 VII 1968, 1 ex., leg. K. Smulikowski [MIZ]; Wetlina, Muchanin Wierch (FV04), 20 VIII 1970, 6 exx. [MIZ].

The most common species of Triplax in Poland.

\section{Triplax scutellaris Charpentier, 1825}

http://species-id.net/wiki/Triplax_scutellaris

Figs 13, 24

Material examined. Białowieża Primeval Forest: Białowieża N.P., 4 VIII 1992, 1 ex., leg. JS [LBJK]. Bieszczady Mts.: Wetlina PGR (FV04), 20 VII 1994, 3 exx., 22 VII 1994, 2 exx., 24 VII 1994, 9 exx., 27 VII 1994, 2 exx., leg. LB [LBJK]; WetlinaJawornik (FV04), 22 VII 1968, 3 exx., leg. K. Smulikowski [MIZ].

This species has been rarely collected in Poland. However, the new findings demonstrate that T. scutellaris is not uncommon in the Bieszczady Mts.

\section{Combocerus glaber (Schaller, 1783)}

http://species-id.net/wiki/Combocerus_glaber

Material examined. Wielkopolska-Kujawy Lowland*: Laski (VU71), xerothermic grassland Potentillo-Stipetum with Stipa joannis Čelak. in a deep ravine surrounded by 


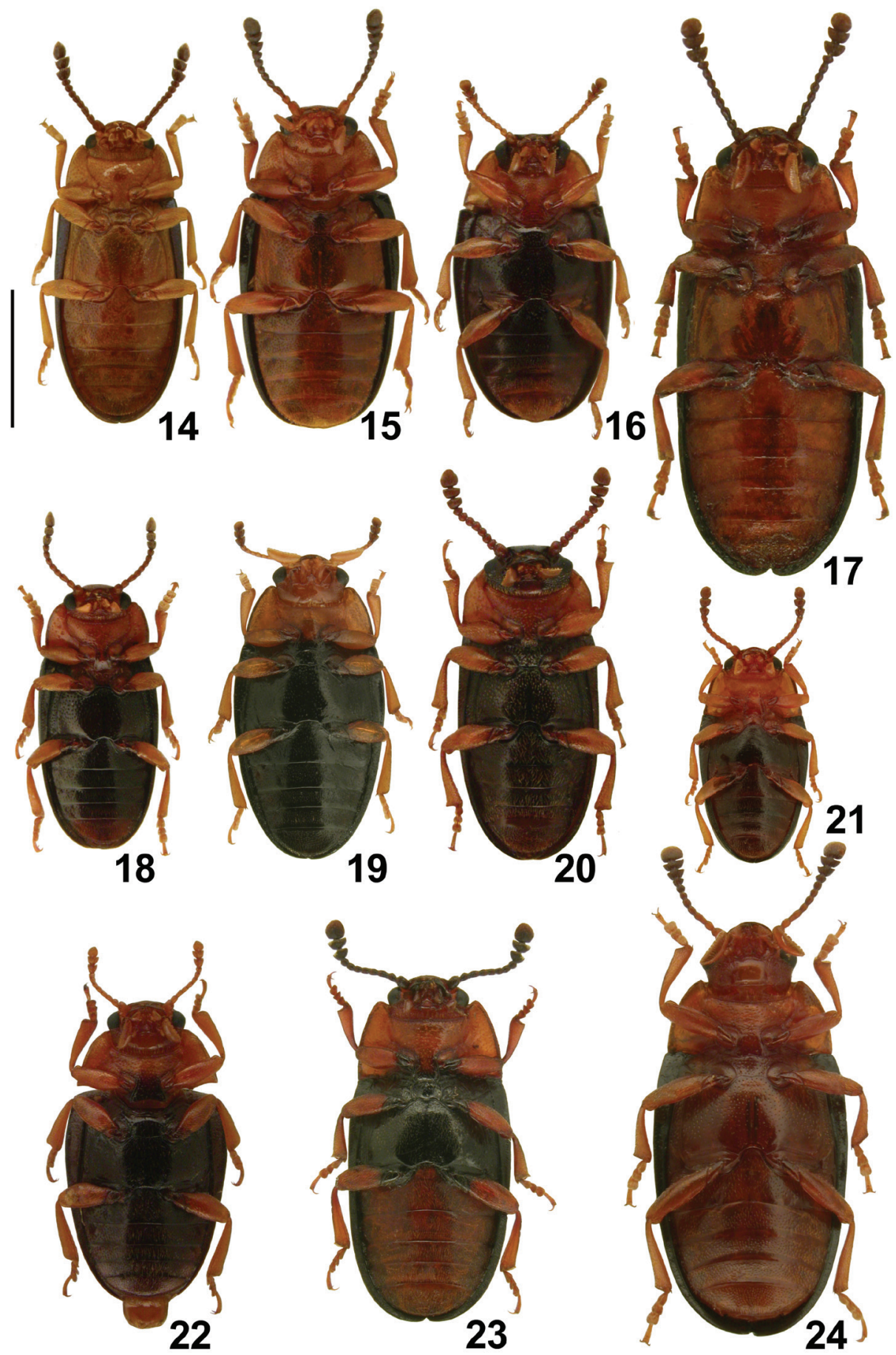

Figures 14-24. Central European species of Triplax, ventral habitus: T. aenea I4 T. carpathica I5 T. collaris $\mathbf{1 6}$ T. elongata $\mathbf{1 7}$ T. lacordairei $\mathbf{1 8}$ T. lepida $\mathbf{1 9}$ T. melanocephala $\mathbf{2 0}$ T. pygmaea $\mathbf{2 1}$ T. rufipes $\mathbf{2 2}$ T. russica 23 and T. scutellaris $\mathbf{2 4}$ Scale bar $=1.0 \mathrm{~mm}$. 


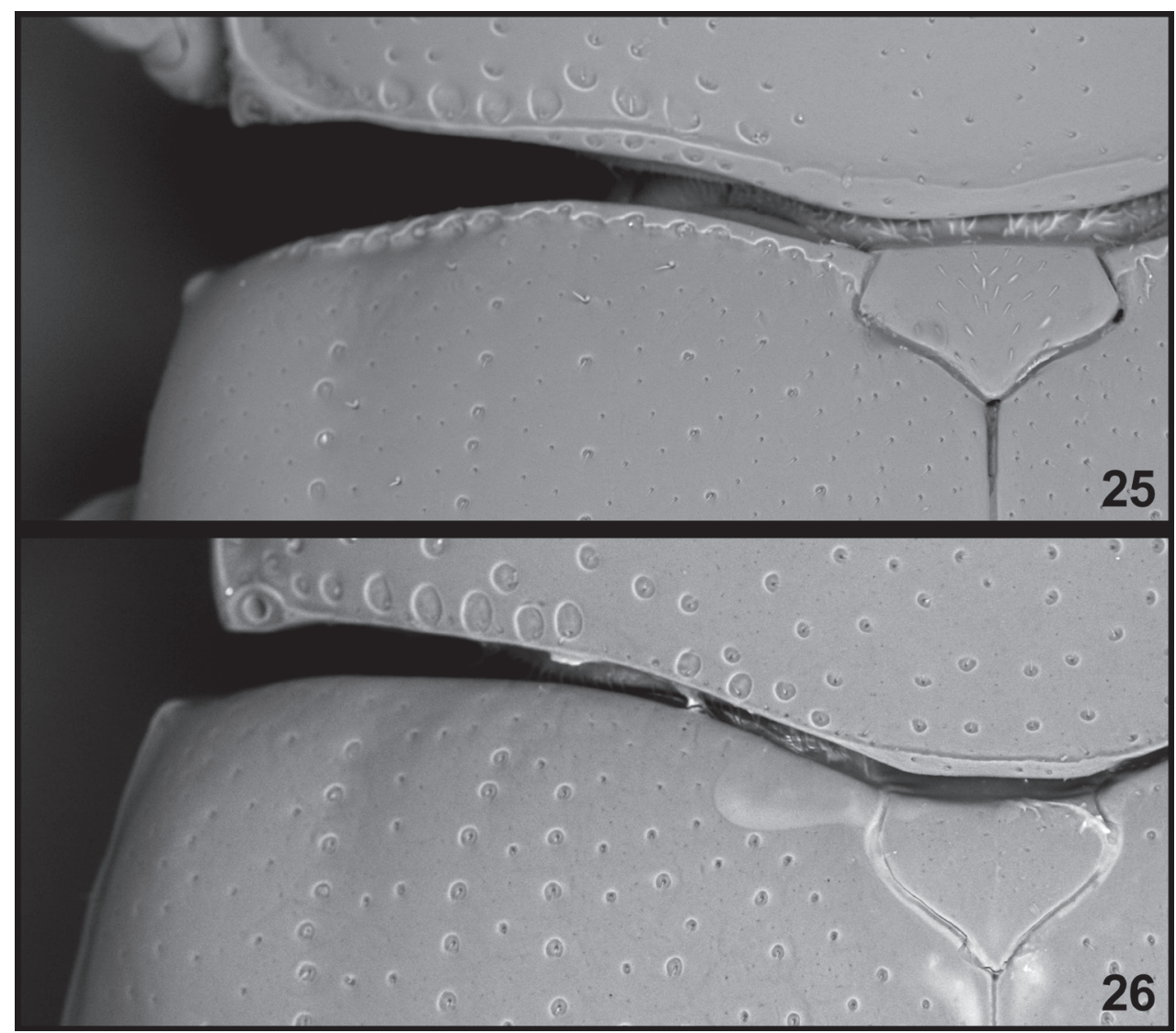

Figures 25-26. Triplax, basal part of elytra (SEM micrographs); Triplax russica $\mathbf{2 5}$ and Triplax scutellaris 26.

fields, 4 VI 2009, 1 ex., leg. PS [SK], 28 V 2010, 1 ex., leg. PS [PJ]; Laski (VU71), xerothermic grassland Adonido-Brachypodietum in a deep ravine surrounded by fields, 28 V 2010, 1 ex., leg. PS [PJ].

This species is rare in Poland, although it has been recorded from scattered localities (Burakowski et al. 1986), and was recently recorded in Poland in the Białowieża Primeval Forest (Byk et al. 2006).

\section{Tritoma subbasalis Reitter, 1896}

http://species-id.net/wiki/Tritoma_subbasalis

Material examined. Podlasie*: Szostaki (EE90) ad Burzyn, 17 VI 2010, 3 exx., leg. RR [RR, SK]. Lublin Upland*: Poleski N.P., Łukie Lake vic. (FB49), 22 V 2004, 2 exx., leg. RR [RR].

This rare species is restricted to the eastern part of Poland. 


\section{Dacne rufifrons (Fabricius, 1775)}

http://species-id.net/wiki/Dacne_rufifrons

Material examined. Bieszczady Mts.: Wetlina State Agricultural Farm (FV04), 27 VII 1994, 2 exx., leg. JK [LBJK].

A rare species, known from scattered localities in various regions of Poland.

\section{Updated key to Triplax species of Central Europe}

Triplax carpathica was not included in any of the previously published identification keys to Central European Erotylidae (Vogt 1967, Mazur 1983). Therefore, an updated key is presented below, comprising all Central European Triplax species (Figs. 3-24). Species known from adjacent areas and which may occur in Poland are denoted with an asterisk.

1 Basal margin of elytra crenulate (Fig. 25), often forming a distinct ridge.....2

Head yellowish-red ............................................................................... 4

Body elongate oval, distinctly rounded; BL 3.3-4.0 mm

T. melanocephala (Latreille)*

Body broadly oval, sides distinctly rounded; BL 3.3-4.0 mm T. collaris (Schaller)

Entire venter yellowish-red. .5

Elytra metallic bluish or greenish; BL 3.6-4.4 mm; sides of body rounded... T. aenea (Schaller)

Elytra black, without metallic hue; BL 6.0-6.5 mm; sides of body subparallel. T. elongata Lacordaire Abdominal sternites yellowish-red; BL 5.1-6.7 mm.... T. russica (Linnaeus) Abdominal sternites entirely or largely black.

T. lacordairei Crotch*

Antennomere III slightly longer than II; BL $2.0-3.0 \mathrm{~mm}$

T. pygmaea Kraatz*

Meso-, metaventrite and abdominal sternites black; body stout (BL/BW 1.71.8); BL 3.3-5.0 mm.

- $\quad$ Entire venter yellowish-red, body larger and more oblong (BL/BW 1.9-2.0).10 Scutellum yellowish-red, elytral punctures shallow; BL 4.2-4.9 ( $\mathrm{n}=16$, mean 4.6) 
- $\quad$ Scutellum always black, eelytral punctures deep; BL 4.1) T. carpathica Reitter

\section{Acknowledgments}

We are indebted to Prof. J. M. Gutowski (Forest Research Institute, Białowieża, Poland) for his kind gift of the T. carpathica specimen used in the present study, Dr. O. Merkl (HNHM) for sending the type of T. carpathica, Dr. W. Schawaller (SMNS) for sending the specimen of T. pygmaea, and Dr. P. Węgrzynowicz (Łódź University, Poland) for confirming our identification of T. carpathica and comments on the genus Cryptophilus. We also thank Prof. L. Borowiec and Dr. J. Kania (Wrocław University, Poland), who made data and specimens from their collections available. The first author's studies were partially supported by the Wrocław University stipend for young researchers financed by The European Social Fund ("Human Resources Development" Operational Programme).

\section{References}

Borowiec L (1984) Triplax carpathica Reitter, 1890 (Col., Erotylidae), a new species of beetle for the fauna of Poland. Przegląd Zoologiczny 28(1): 73-74. [In Polish]

Burakowski B, Mroczkowski M, Stefańska J (1973) Chrząszcze Coleoptera, Biegaczowate Carabidae, cz. 1. Catalogus faunae Poloniae XXIII, 2: 1-234. [In Polish]

Burakowski B, Mroczkowski M, Stefańska J (1986) Chrząszcze Coleoptera, Cucujoidea, cz. 2. Catalogus faunae Poloniae XXIII, 13: 1-278. [In Polish]

Byk A, Mokrzycki T, Perliński S, Rutkiewicz A (2006) Saproxylic beetles - in the monitoring of anthropogenic transformations of Białowieża Primeval Forest. In: Szujecki A (Ed) Zooindication-based monitoring of anthropogenic transformations in Białowieża Primeval Forest. Warsaw Agricultural University Press, Warsaw, 325-397.

Chûjô M (1969) Erotylidae (Insecta: Coleoptera). Fauna Japonica. Academic Press of Japan, Tokyo, 316 pp.

Franc V (2001) Beetles of the family Erotylidae (Coleoptera) in the Slovakian fauna. Acta Universitatis Comenianae 44: 63-69.

Ganglbauer L (1899) Die Käfer von Mitteleuropa. Die Käfer der österreichisch-ungarischen Monarchie, Deutschlands, der Sweiz, sowie des französischen und italienischen Alpengebietes. Dritter Band. Familienreiche Clavicornia. Sphaeritidae, Ostomidae, Byturidae, Nitidulidae, Cucujidae, Erotylidae, Phalacridae, Thorictidae, Lathridiidae, Mycetophagidae, Colydiidae, Endomychidae, Coccinellidae. [II]. Druck und Verlang Carl Gerold's Sohn, Wien, 409-1046.

Iablokoff-Khnzorian S M (1975) Etude sur les Erotylidae (Coleoptera) Paléarctiques. Acta Zoologica Cracoviensia 20: 201-266. 
Jałoszyński P, Węgrzynowicz P (2007) A new record of Triplax collaris (Schaller) in Poland (Coleoptera, Erotylidae). Entomological News (Poznań) 26(1): 61-62. [In Polish] http:// pte. au.poznan.pl/we/2007/10_kr_don.pdf [accessed 7.VI.2011]

Lawrence J (1991) Languriidae (Cucujoidea) (including Crytophilidae), Erotylidae (Cucujoidea) (including Dacnidae), Biphillidae (Cucujoidea), pp. 471-476. In: Stehr FW (ed.) Immature Insects. Vol. 2. Kendall/Hunt Publishing Company, Dubuque, Iowa.

Leschen RAB, Buckley TR (2007) Multistate Characters and Diet Shifts: Evolution of Erotylidae (Coleoptera). Systematic Biology 56(1): 97-112. doi: 10.1080\%2F10635150701211844

Mazur S (1983) Zadrzewkowate - Erotylidae, Wygłodkowate - Endomychidae. Keys for the identification of Polish insects XIX, 74-75: 1-32. [In Polish]

Nieto A, Alexander KNA (2010) European Red List of Saproxylic Beetles. Luxembourg: Publications Office of the European Union: 1-44. http://ec.europa.eu/environment/nature/conservation/species/redlist/downloads/European_saproxylic_beetles.pdf [accessed 7.VI.2011]

Reitter E (1890) Neue Coleopteren aus Europa, den angrenzeden Ländern und Sibirien, mit bemerkungen über bekannte Arten. Deutsche Entomologische Zeitschrift 1890: 385-396.

Sen Gupta T, Crowson RA (1971) A review of classification of the family Languriidae (Coleoptera: Clavicornia) and the place of Languriidae in the natural system of Clavicornia. Memoirs of the Zoological Survey of India 15: 1-42.

Vogt H (1967) Erotylidae. In: Fraude H, Harde KW, Lohse GA (eds.) Die Käfer Mitteleuropas. Band 7. Clavicornia. Goecke und Evers, Krefeld: 104-109.

Węgrzynowicz P (2002) Morphology, phylogeny and classification of the family Erotylidae based on adult characters (Coleoptera: Cucujoidea). Genus 13(4): 435-504. http://www. biol.uni.wroc.pl/cassidae/Erotylidae\%20classification.pdf [accessed 7.VI.2011]

Węgrzynowicz P (2007) Family Erotylidae Latreille, 1802. In: Löbl I, Smetana A (eds.) Catalogue of Palaearctic Coleoptera, vol. 4. Apollo Books, Stenstrup, 935 pp. 